\title{
Role of intradialytic oral nutrition therapy in Indian patients
}

\author{
Raksha Goyal ${ }^{1, *}$, Nandini Sarwate ${ }^{2}$ \\ ${ }^{1}$ PHD Scholar, ${ }^{2}$ Professor, ${ }^{1}$ Devi Ahilya Vishvidyalaya, Indore Madhya Pradesh, ${ }^{2}$ Government Mata Jija Bai Girls PG College, \\ Indore, Madhya Pradesh, India \\ *Corresponding Author: \\ Email: rakshagoyal20@gmail.com
}

\begin{abstract}
Malnutrition is common in patients with chronic renal failure (CRF), and its prevalence before the initiation of dialysis is poorly characterized in these patients in developing countries. There is a paucity of data on the quantification of malnutrition and inflammation in undialyzed patients of CRF from India. Besides the medical condition like anorexia, nausea, vomiting, uraemia etc there are some vegetarian diet pattern and religious factors which abstinence the patients from consuming high biological value protein. This enhances the gap between daily nutrition requirement and fulfilment of the same. Here the oral nutritional supplement appears to be a sustainable effort toward addressing malnutrition in maintenance haemodialysis patients.
\end{abstract}

Keywords: CRF, Dialysis, Malnutrition, Oral nutrition supplements, Albumin.

\section{Introduction}

Malnutrition is a frequent complication which affects quality of life and is associated with increased risk of mortality and morbidity in maintenance haemodialysis patients. ${ }^{1,2}$

Decreased nutritional intake may be a function of uraemia itself, leading to anorexia that may also be associated with disorders in taste, fatigue, and nausea and/or vomiting. ${ }^{11,12}$

It is recommended to screen the nutritional status of the patient before dialysis so that the quality of treatment can be improved. The various methods used for assessment of nutritional status are time consuming and complex. Subjective global assessment (SGA) scores, determined by medical history on seven items and clinical findings on four items, is a well-validated tool for screening for malnutrition. ${ }^{4-6}$

Albumin has also maintained a prominent role as a practical marker with a very strong association with morbidity and mortality in haemodialysis patients. $^{3}$ Serum albumin is a valid and clinically useful measure of protein-energy nutritional status in MHD patients. Hypoalbuminemia is highly predictive of future mortality risk and measurement of serum albumin is inexpensive, easy to perform and widely available.

\section{Indian Scenario}

In India there is a high prevalence of protein energy malnutrition in patients with end stage renal disease (ESRD) and the calorie and protein intake of Indian patients with ESRD is poor. There is a paucity of data regarding the prevalence and clinical consequences of protein-energy malnutrition (PEM) in the chronic renal failure, maintenance dialysis, and renal transplant population in developing countries. Malnutrition, which is reported to be present in $42 \%$ to $77 \%$ of the end-stage renal disease population in developing countries is strongly associated with morbidity and mortality.

Malnutrition in Indian patients is often severe and multifactori al. Reasons include late initiation of PD protein restriction in the pre dialysis period recurrent infections, co morbidity, and dietary factors. Patients almost invariably fall short of recommended dietary intakes. ${ }^{7}$

Many religious practices in developing countries promote abstinence from meat, fish, and eggs. Both a vegetarian dietary pattern which is being adopted by an increasing number of people, and ingestion of inadequate protein and calories in the diet to arrest the progression of chronic renal failure, may lead to malnutrition. The attendant complications of PEM, malaise, wasting, anaemia, and decreased immunity may predispose these patients to infections. This is commonly seen in both the maintenance haemodialysis and peritoneal dialysis population and may decrease their surviv al.

Vegetarianism is very common in India that means the patients do not get animal source protein in their diet. Dietary habits are also complex with many patients being pure vegetarians, some who occasionally partake of meat in the diet and some who are regular non vegetarians. This makes nutritional assessment and management difficult. Data on Indian patient's nutritional status is scant. A recent trial showed that malnutrition at initiation of PD was predictive of higher incidence of peritonitis.

\section{Daily Nutritional Requirement}

Indian PD patients are thought to consistently fail to achieve NKF-KDOQI recommended calorie and protein intake, which was confirmed in some Indian studies. $^{8}$

The recommended dietary energy intake (DEI) for patients undergoing haemodialysis and peritoneal dialysis is $30-35 \mathrm{kcal} / \mathrm{kg}$ per day. ${ }^{8,9,10}$ Suggested mean dietary protein intake (DPI) is $1.2 \mathrm{~g} / \mathrm{kg}$ per day in patients on haemodialysis and $1.3 \mathrm{~g} / \mathrm{kg}$ per day in patients on peritoneal dialysis. ${ }^{8,9,10}$ Most patients on dialysis, however, have a lower DEI and DPI than the recommended intake. 


\section{Role of Oral Nutrition Supplements}

Oral supplementation can provide an additional 7-10 $\mathrm{kcal} / \mathrm{kg}$ per day of energy and $0.3-0.4 \mathrm{~g} / \mathrm{kg}$ per day of protein, which makes it possible to meet the recommended targets of both DEI and DPI. ${ }^{8}$

Increasing protein and caloric intake coincident with the thrice-weekly haemodialysis treatments may facilitate achieving sufficient nutritional support to improve physiologic processes enough to delay death. ${ }^{31}$

Intradialytic oral nutritional supplements may help address the catabolic impact of the haemodialysis procedure. ${ }^{13,14}$ In addition to direct losses of amino acids to the dialysate (which some estimates have equated to the loss of up to $15 \mathrm{~g}$ of protein each treatment). ${ }^{15-17}$ hemodialysis has been shown to result in a net catabolic state that predisposes to protein breakdown due to activation of inflammatory mediators. ${ }^{18-19}$

Table1summarize some Indian studies which unveil the existence of malnutrition of the renal patients before and during RRT and Table 2 summarize some studies where authors have divulged the effect of intradialytic oral nutrition therapy on the nutritional status, albumin level and quality of life of the renal patients.

\section{Literature of Review}

A nutritional assessment conducted by Prasad et al. (2008). ${ }^{7}$ concluded that $67.8 \%$ renal patients are mild to moderately malnourished where as $7 \%$ are severely malnourished at the time of initiation of dialysis.

In another study conducted by Prakash et al (2007). ${ }^{20}$ on 203 Indian renal patients concluded that $66 \%$ patients are initially malnourished with low serum albumin level $3.18 \mathrm{mg} / \mathrm{dl}$.

Prasad et al. (2007). ${ }^{21}$ has showed a higher incidence of peritonitis in malnourished renal patients.

CKD specific oral nutrition supplements intervention for 3-6 months to haemodialysis patients had been showed a significant increase in albumin concentration by $2.2 \mathrm{gm} / 1$ to $3.2 \mathrm{gm} / 1 .{ }^{24,25,26,28,29}$

Table1. Prevalence of malnutrition in CKD patients in India.

\begin{tabular}{|l|c|c|c|c|}
\hline \multicolumn{1}{|c|}{ Study } & $\begin{array}{c}\text { N/Location/ Dialysis } \\
\text { Modality }\end{array}$ & $\begin{array}{c}\text { Study Design and } \\
\text { Duration }\end{array}$ & $\begin{array}{c}\text { Evaluation } \\
\text { modalities }\end{array}$ & Results \\
\hline $\begin{array}{l}{ }^{7} \text { Prasad et. al. } \\
(2008)\end{array}$ & $283 /$ India/ PD & Follow up study & $\begin{array}{c}\text { Nutritional } \\
\text { assessment }\end{array}$ & $\begin{array}{c}67.8 \% \text { mild to } \\
\text { moderate } \\
\text { malnourished, } 7 \% \\
\text { severe } \\
\text { malnourished at the } \\
\text { initiation of } \\
\text { dialysis. }\end{array}$ \\
\hline $\begin{array}{l}{ }^{20} \text { Prakash et. al. } \\
(2007)\end{array}$ & $203 /$ India/CRF & 2 yrs. & $\begin{array}{c}\text { Nutritional and } \\
\text { anthropometric } \\
\text { assessment }\end{array}$ & $\begin{array}{c}65 \% \text { alnourished, } \\
\text { with low albumin } \\
\text { level 3.18 mg/dl. }\end{array}$ \\
\hline $\begin{array}{l}{ }^{21} \text { Prasad et. al. } \\
(2007)\end{array}$ & $56 /$ India/ PD & ---- & $\begin{array}{c}\text { Nutritional } \\
\text { assessment and } \\
\text { episodes of } \\
\text { Peritonitis }\end{array}$ & $\begin{array}{c}\text { Higher incidence of } \\
\text { peritonitis in } \\
\text { malnourished } \\
\text { patients. }\end{array}$ \\
\hline $\begin{array}{l}{ }^{22} \text { Janardhan et. } \\
\text { al. (2011) }\end{array}$ & 60/ India/ HD & 6 Month & $\begin{array}{c}\text { Nutritional } \\
\text { assessment }\end{array}$ & $\begin{array}{c}91 \% \text { malnourished } \\
\text { with low albumin } \\
\text { level. }\end{array}$ \\
\hline $\begin{array}{l}{ }^{23} \text { Tapiawala et. } \\
\text { al. (2006) }\end{array}$ & $81 /$ India/ ESRD & ---- & $\begin{array}{c}\text { Nutritional and } \\
\text { anthropometric } \\
\text { assessment }\end{array}$ & $\begin{array}{c}48 \% \text { with CRI, } 50 \% \\
\text { on CAPD, 58\% on } \\
\text { HD are } \\
\text { malnourished. }\end{array}$ \\
\hline
\end{tabular}

Table2. Effect of intradialytic oral nutritional interventions on the nutritional status and serum albumin levels of the dialysis patients.

\begin{tabular}{|l|l|c|c|}
\hline \multicolumn{1}{|c|}{ Study } & \multicolumn{1}{|c|}{ Intervention Modality } & $\begin{array}{c}\text { Study design } \\
\text { and duration }\end{array}$ & Results and conclusions \\
\hline $\begin{array}{l}{ }^{24} \text { Eustace et } \\
\text { al. (2000) }\end{array}$ & $\begin{array}{l}\text { Essential Amino Acids (EAA) (3.6g } \\
\text { with meals three-times daily) vs } \\
\text { placebo. }\end{array}$ & for 3 months & $\begin{array}{l}\text { Serum albumin concentration } \\
\text { in HD patients (EAA vs } \\
\text { placebo) increased by 2.2 g/l. }\end{array}$ \\
\hline
\end{tabular}




\begin{tabular}{|c|c|c|c|}
\hline $\begin{array}{l}{ }^{25} \text { Sharma et } \\
\text { al. }(2002)\end{array}$ & $\begin{array}{l}\text { CKD-specific ONS } 500 \mathrm{kcal} \text { and } \\
15 \mathrm{~g} \text { protein vs standard home- } \\
\text { prepared ONS }(500 \mathrm{kcal} \text { and } 15 \mathrm{~g} \\
\text { protein) vs routine care }\end{array}$ & for 1 month & $\begin{array}{l}\text { Significant increase in } \\
\text { albumin concentration in the } \\
\text { groups receiving CKD- } \\
\text { specific ONS and home- } \\
\text { prepared ONS vs routine care } \\
\text { (39 g/l and } 40 \mathrm{~g} / \mathrm{l} \text { vs } 35 \mathrm{~g} / \mathrm{l}, \\
\text { respectively). }\end{array}$ \\
\hline $\begin{array}{l}{ }^{26} \text { González- } \\
\text { Espinoza et } \\
\text { al. (2005) }\end{array}$ & $\begin{array}{l}\text { Egg albumin-based ONS; open-label } \\
\text { controlled trial with }\end{array}$ & $\begin{array}{l}\text { 6-month } \\
\text { follow-up }\end{array}$ & $\begin{array}{l}\text { Serum albumin levels } \\
\text { increased from } 26.4 \mathrm{~g} / \mathrm{l} \text { to } \\
30.5 \mathrm{~g} / \mathrm{l} \text { in the study group vs } \\
26.6 \text { to } 28.0 \mathrm{~g} / \mathrm{l} \text { in the control } \\
\text { group. }\end{array}$ \\
\hline $\begin{array}{l}{ }^{27} \text { Moretti et } \\
\text { al. (2009) }\end{array}$ & Standard ONS & $\begin{array}{l}\text { for } 1 \text { year; } \\
\text { crossover } \\
\text { controlled trial }\end{array}$ & $\begin{array}{c}\text { Serum albumin levels } \\
\text { increased from } 34.9 \mathrm{~g} / \mathrm{l} \text { to } \\
35.2 \mathrm{~g} / \mathrm{l} \text { at } 3 \text { months in the } \\
\text { group receiving ONS. }\end{array}$ \\
\hline $\begin{array}{l}{ }^{23} 8 \text { Beutler } \\
\text { et al. } \\
\text { (1997) }\end{array}$ & CKD-specific ONS vs usual diet & for 4 months & $\begin{array}{l}\text { Albumin levels increased } \\
\text { with ONS from } 32.0 \mathrm{~g} / \mathrm{l} \text { to } \\
33.2 \mathrm{~g} / \mathrm{l} .\end{array}$ \\
\hline $\begin{array}{l}{ }^{29} \text { Caglar et } \\
\text { al. }(2002)\end{array}$ & $\begin{array}{l}\text { In-center CKD-specific ONS thrice- } \\
\text { weekly on hemodialysis }(415 \mathrm{kcal} \\
\text { and } 16.6 \mathrm{~g} \text { protein per session) }\end{array}$ & $\begin{array}{l}\text { for } 6 \text { months; } \\
\text { observation and } \\
\text { intervention }\end{array}$ & $\begin{array}{l}\text { During intervention period, } \\
\text { albumin levels increased } \\
\text { from } 33.3 \mathrm{~g} / \mathrm{l} \text { to } 36.5 \mathrm{~g} / \mathrm{l} .\end{array}$ \\
\hline $\begin{array}{l}{ }^{30} \text { Kalantar- } \\
\text { Zadeh et al. } \\
(2005)\end{array}$ & $\begin{array}{l}\text { In-center (dialysis clinic) with low } \\
\text { albumin concentration } \leq 38 \mathrm{~g} / \mathrm{l} \mathrm{CKD}- \\
\text { specific ONS thrice-weekly on HD }\end{array}$ & for 4 weeks & $\begin{array}{c}\text { Pre-trial serum albumin } \\
\text { levels }(34.5 \pm .1 \mathrm{~g} / \mathrm{l}) \text { increased } \\
\text { to } 36.8 \pm .4 \mathrm{~g} / \mathrm{l} \text { between } 18 \\
\text { and } 26 \text { days after the start of } \\
\text { the intervention. }\end{array}$ \\
\hline
\end{tabular}

\section{Discussion}

We identified peer review articles published on the prevalence of malnutrition in renal patients and the effect of nutritional intervention on the health status of the Indian patients. Twelve articles were analysed for the systemic literature review.

Thus malnutrition is common in patients with CRF before the commencement of dialysis, so an emphasis should be placed on the regular assessment of nutritional status of CRF patients to avoid the adverse events during dialysis.

Poor nutrition in dialysis patients is associated with increased morbidity and mortality in the form of delayed wound healing, malaise, fatigue, increased susceptibility to infection and poor rehabilitation. Nutritional needs are enhanced in presence of stresses like infection or surgery to limit excessive tissue catabolism and therefore, these are the situations, which demand intensive nutrition therapy.

The studies evaluated showed $60 \%$ patients of renal disease are already malnourished before undergoing to dialysis in India. After a nutritional intervention for at least 3 months an average serum albumin level is increased by $2.2 \mathrm{gm} / 1-3.5 \mathrm{gm} / 1$.

\section{Conclusion}

It has been concluded that the oral nutritional supplement appears to be a sustainable effort toward addressing malnutrition in maintenance haemodialysis patients. These may subsides the gap between the daily energy requirement and energy consumption by the patients.

\section{References}

1. Neumayer LA, Smout RJ, Horn HG, Horn SD. Early and sufficient feeding reduces length of stay and charges in surgical patients. J Surg Res. 2001;95:73-77.

2. Heys SD, Walker LG, Smith I, Eremin O. Enteral nutritional supplementation with key nutrients in patients with critical illness and cancer: A meta-analysis of randomized controlled clinical trials. Ann Surg. 1999;229:467-77.

3. Kalantar-Zadeh K, Kilpatrick RD, Kuwae N, et al. revisiting mortality predictability of serum albumin in the dialysis population: time dependency, longitudinal changes and populationattributable fraction. Nephrol Dial Transplant. 2005;20(9):1880-88.

4. Persson C, Sjoden PO, Glimelius B. The Swedish version of the patient-generated subjective global assessment of nutritional status: Gastrointestinal Vs urological cancers. Clin Nutr. 1999;18:71-77.

5. Detsky AS, Baker JP, Mendelson RA, Wolman SL, Wesson DE, Jeejeebhoy KN. Evaluating the accuracy of nutritional assessment techniques applied to hospitalized patients: Methodology and comparisons. J Parenter Enteral Nutr. 1984;8:1539.

6. Julien JP, Combe C, Lasseur C. Subjective global assessment of nutrition a useful diagnostic tool for nurses. Edtna/ERCA J. 2001;27:193-96.

7. Prasad N, Gupta A, Sinha A, Sharma RK, Kumar A, Kumar R. Changes in nutritional status on follow-up of an incident cohort of continuous ambulatory peritoneal dialysis patients. J Ren Nutr. 2008;18:195-201. 
8. National Kidney Foundation. K/DOQI Clinical Practice Guidelines for nutrition in Chronic Renal Failure. Am J Kidney Dis. 2000;35(6)2:S1-S40.

9. Toigo, G. et al. Expert Working Group report on nutrition in adult patients with renal insufficiency (part 2 of 2). Clin. Nutr. 2000;19:281-29.

10. Fouque, D. et al. EBPG guideline on nutrition. Nephrol. Di al. Transplant. 22 (Suppl. 2), ii45-ii87 (2007).

11. Bergstrom J. Anorexia in dialysis patients. Semin Nephrol. 1996;16(3):222-29.

12. Virga G, Mastrosimone S, Amici G, Munaretto G, Gastaldon F, Bonadonna A. Symptoms in hemodialysis patients and their relationship with biochemical and demographic parameters. Int J Artif Organs. 1998;2(12):788-93.

13. Wingard RL, Chan KE, Lazarus JM, Hakim RM. The "right" of passage: surviving the first year of dialysis. Clin J Am Soc Nephrol. 2009;4(1):S114-S120.

14. Veeneman JM, Kingma HA, Boer TS, et al. Protein intake during hemodialysis maintains a positive whole body protein balance in chronic hemodialysis patients. Am J Physiol Endocrinol Metab. 2003;284(5):954-65.

15. Ikizler TA, Flakoll PJ, Parker RA, Hakim RM. Amino acid and albumin losses during hemodialysis. Kidney Int. 1994;46(3):830-37.

16. Kirschbaum B. CBQCA assay of primary amine losses during hemodialysis. Clin Chim Acta. 2001;308(1-2):14753.

17. Gil HW, Yang JO, Lee EY, Lee EM, Choi JS, Hong SY. The effect of dialysis membrane flux on amino acid loss in hemodialysis patients. $J$ Korean Med Sci. 2007;22(4):598-603.

18. Ikizler TA, Pupim LB, Brouillette JR, et al. Hemodialysis stimulates muscle and whole body protein loss and alters substrate oxidation. Am J Physiol Endocrinol Metab. 2002;282(1):107-16.

19. Caglar K, Peng Y, Pupim LB, et al. Inflammatory signals associated with hemodialysis. Kidney Int. 2002;62(4):1408-16.

20. Prakash J, Raja R, Mishra RN, Vohra R, Sharma N, Wani IA, Parekh A. High prevalence of malnutrition and inflammation in undialyzed patients with chronic renal failure in developing countries: a single center experience from eastern India. Ren Fail. 29(7):811-16.
21. Prasad N, Gupta A, Sharma RK, Sinha A, Kumar R. Impact of nutritional status on peritonitis in CAPD patients. Perit Dial Int. 2007;27:42-47.

22. Janardhan V, Soundararajan P, Rani NV, Kannan G, Thennarasu P, Chacko RA, Reddy CU. Prediction of Malnutrition using modified subjective global assessment - dialysis malnutrition score in patients on hemodialysis. Indian J Pharm Sci. 2011;73(1):38-45.

23. Tapiawala S, Vora H, Patel Z, Badve S, Shah B Subjective global assessment of nutritional status of patients with chronic renal insufficiency and end stage renal disease on dialysis. $J$ Assoc Physicians India. 2006;54:923-26.

24. Eustace, J. A. et al. Randomized double-blind trial of oral essential amino acids for dialysis-associated hypoalbuminemia. Kidney Int. 2000;57:2527-38.

25. Sharma, M., Rao, M., Jacob, S. \& Jacob, C. K. A controlled trial of intermittent enteral nutrient supplementation in maintenance hemodialysis patients. $J$ Ren. Nutr. 2002;12:229-37.

26. González-Espinoza, L. et al. Randomized, open label, controlled clinical trial of oral administration of an egg albumin-based protein supplement to patients on continuous ambulatory peritoneal dialysis. Perit Di al. Int. 2005;25:173-180.

27. Moretti, H. D., Johnson, A. M. \& Keeling-Hathaway, T. J. Effects of protein supplementation in chronic hemodialysis and peritoneal dialysis patients. J. Ren. Nutr. 2009;19:298-303.

28. Beutler, K. T., Park, G. K. \& Wilkowski, M. J. Effect of oral supplementation on nutrition indicators in hemodialysis patients. J Ren. Nutr. 1997;7:77-82.

29. Caglar, K. et al. Therapeutic effects of oral nutritional supplementation during hemodialysis. Kidney Int. 2002;62:1054-59.

30. Kalantar-Zadeh, K. et al. An anti-inflammatory and antioxidant nutritional supplement for hypoalbuminemic hemodialysis patients: a pilot/feasibility study. J Ren Nutr. 2005;15:318-31.

31. Lacson E Jr, Wang W, Zebrowski B,Wingard R, Hakim RM. Outcomes Associated With Intradialytic Oral Nutritional Supplements in Patients Undergoing Maintenance Hemodialysis. A Quality Improvement Report. Am J Kidney. 2012;10. 